\title{
Accounting
}

\section{Factors influencing spread in Malaysia securitization market}

\author{
Mohammed Hariri Bakri ${ }^{a *}$, Shafinar Ismail ${ }^{\text {b }}$, Nurazilah Zainal ${ }^{c}$, Fakarudin Kamarudin ${ }^{d}$ and \\ Samer Al Shami ${ }^{\mathrm{e}}$
}

\author{
${ }^{a}$ Faculty of Technology Management and Technopreneurship, Universiti Teknikal Malaysia Melaka, Hang Tuah Jaya,76100, Durian \\ Tunggal, Melaka,Malaysia \\ ${ }^{b}$ Faculty of Business and Management, Universiti Teknologi MARA, Melaka 75300, Malaysia \\ ${ }^{c}$ Faculty Of Business Management, Universiti Teknologi MARA (UiTM) Cawangan Negeri Sembilan, Kampus Seremban, Persiaran \\ Seremban Tiga/1, Seremban 3, 70300 Seremban, Negeri Sembilan, Malaysia \\ ${ }^{d}$ Faculty of Economics and Management, Universiti Putra Malaysia, 43400 Serdang, Selangor Darul Ehsan, Malaysia \\ eInstitute of Technology Management and Technopreneurship, Universiti Teknikal Malaysia Melaka, Hang Tuah Jaya,76100, Malaysia
}

\section{H R O N I C L E}

\section{Article history:}

Received March 312020

Received in revised format March

312020

Accepted April 232020

Available online

April 232020

Keywords:

Spread

Securitization

Leverage

Panel data

Malaysia

\begin{abstract}
The purpose of this paper is to propose a model to test the factors influencing on spread in Malaysia securitization market. An extension Vink's model is tested and revalidated to determine and measure the factors influencing spread of securitized firms in Malaysia. The study consists firm characteristics and macroeconomic factors. Firm characteristic factors based on Vink's model, such as Liquidity and Leverage. In addition, economic and market condition factors such as Interest and Inflation also maintain high impact to spread securitized firms. Ordinary Least square method, Panel data and multiple regression analysis are applied for the study period 2004-2012. The result shows two determinants influence or contribute to the primary market spread and are statistically significant in developing the securitization in Malaysia. It can be concluded that inflation and interest rate significantly contribute to the determinant of primary market spread. From four hypotheses, two hypotheses support that the determinants had a relationship with primary market spread. The result may become a model and benchmark for other ASEAN countries to be used as Malaysia resilient during subprime mortgage in 2008.
\end{abstract}

\section{Introduction}

Asset Backed Securities (ABS) in the US and Europe are rising extremely and they have concerned numerous fixed income depositors to discover in this ABS market for a diversity of asset assignment. The methods are more compound and complex monetary instrumented, Giddy (2000) predicts that ABS had an aptitude to handover risk with little loss of income by a departure of good monetary asset for a company. Securitization by finding procedure is the course where uniform but illiquid asset's pooling and packaging process is performed with security interest based on incoming cash flows and sold to third party investors (Lumpkin, 1999). Since October 2012, ABS has represented alternative long-term funding of auto loans, lease, credit card receivables and commercial mortgages. For the case of Malaysia, the Malaysian Market Cagamas, was formed in 1986 based

* Corresponding author. Tel: +6013-9126699

E-mail address: hariri@utem.edu.my (M. H. Bakri) 
on Fannie Mae and Freddie Mac of USA (Gangwani, 1998). Therefore, Cagamas utilities as a Special Purpose Vehicle (SPV) between investor of long-term funds and house mortgage lenders, is the major imperative matter of securities tools in Malaysia by far. Securitization market in Malaysia was only estimated at RM45.5 billion at the end of 1996 and this is due to the fact that the other parts of asset, instead of Cagamas, have not been very strong. The Securities Commission (SC) in 2001 provided obligatory rules securitization of asset and released its rules on the Offering of ABS. On the tenth of April 2001, regarding its possible important involvement to the debt market of Malaysia, it provided a contribution for insuring Collateralized Bond Obligation (CBO) with the help of Prisma Assets Berhad (2001) which was supported through Ringgit-denominated bonds' pool. An additional CBO deal was supported by Collateralized Loan Obligation (CLO) and by corporate bonds supported by recovering business loans pursuit in the same year. Till December 2012, an anticipated 101 planned dealings have been accepted underneath the Securities Commissions (SC) rules on private debt securities, ABS and supplementary planned merchandises, all of which encompassed an array of asset classes. In a related development in Malaysia, sukuk grew to over US148bil (RM473.7billion) as at June 2013 from US1.5 billion (RM4.8billion) in 2001. The Malaysian sukuk comprises $60.4 \%$ from outstanding sukuk in other parts of the world (Fong, 2013). The researchers here are motivated to find the determinant of the primary market spread of Asset Back Securities to develop it in Malaysia and set to become the best alternative resource for capital structure in order to raise funds, the Security Commission in Malaysia introduced guideline on how to issue asset-backed securitization (ABS) in 2001. The securitization is a creative process of raising funds by issuing marketable securities that are backed by future cash flows from revenue producing assets. Until October 2012, ABS represented alternative long-term funding of auto loans, lease, credit card receivables and commercial mortgages (Bakri et al., 2015). Apart from mortgages securitized by Cagamas, securitization of other assets has not been very strong in Malaysia, so here researcher would like to focus on ABS compared with other type of securitization such as Collateral Debt Obligation (CDO) and others.

The objective of this study is to examine both internal (company specific) and external (macroeconomic market condition) determinants of the primary market spread. We investigate the selected determinants of the primary market spread based on the regression model and main factors that determine primary market spread. We also discover issues and impact of spread in securitization in the primary market in Malaysia. The research question involved is what are the most influence factor of Primary Market Spread? Based on regression model by Vink (2008), the study will examine the determinants of primary market spread which are suitable to develop an Asset Backed Securitization model in Malaysia. The significance of this study is related to corporations which Asset Back Securities alternative cheaper source of fund and securities with Sukuk and Bond reduce of the cost of bankruptcy by setting up a Special Purpose Vehicle and company will use our result to determine what variable influence and significance to the primary market spread (Bakri et al., 2016). Significance to investors where the buyer from capital market would be able to get a superior return than current instrument such as Fixed Deposit with the right price. The limitation of this study is on determinant of primary market spread and not on secondary market and the data collection of Malaysia Companies.

In view of the fact that from 1970s, there are numerous broad studies associated to issues that influence the corporate bond pricing, few experiential proofs on the issues affect the residential mortgage-backed securities (RMBS) price in nearly developed countries counting Malaysia. Malaysia is recognized as a main division of the bond market (Fabozzi \& Vink, 2012). In the UK, RMBS is established to be the major securitization division and a large amount of experiential proofs on the issues that influence pricing subject of RMBS has been reported. Despite the fact that Cagamas is the major factor for Residential and Commercial Mortgage-Backed Securities (CMBS), there are few studies on primary market spread determinants including Tranches, Credit Rating, Enhancement, Lead Manager, Rating Agencies, Transaction Size, Loan Size, Maturity, Loan to Value, Retained, Year of Issue, Type of Interest Rate, Currency and Currency Risk (Vink, 2008). Consequently, this research aims to fill the research gap of primary market spread securitization in Malaysia with reference to Liquidity and Leverage.

In forecasting CMBS loan performance, Seagraves (2012) suggested supplementary data regarding the loan originators including firm type, that is the degree that originators keep an equity stake in aiming CMBS. The discovery of his study contributes that a shareholder must not depend merely on a certain issue, including credit rating and should consider additional issues including leverage and liquidity as suggested by Fabozzi and Vink (2012). This entails that shareholders emerge not to depend completely on these ratings despite the fact that credit ratings contribute as chief position in establishing spreads since a lot of additional issues compromising enhancement, loan to value, nature of asset, time of issue and number of trenches (Ali et al., 2015).The discussions conducted by Fabozzi (1998), Riddiough (1997), Black and Scholes (1973) and Ingersol (1987) propose the worth of an extracted security including Collateralized Mortgage Obligation (CMO) can be traced to a particular set of fundamental factors including discount rates and cash flow to conclude an arbitrage-free price. They propose that security prices can diverge from basic worth. Gordon (1959), Summers (1986) and Schiller (1989) discuss that the primary values are dissimilar since shareholders price the securities in a different way. However, the continuation of an extraction from essentials can point out that the market for those securities is not working proficiently, despite the fact that it is considered that this extraction will make an arbitrage occasion. As discussed earlier, previous securitization in the US, European and worldwide capital markets are increasing extremely. Recently, securitization has achieved secured position in business financing and investment group, since it supplies originators an inexpensive basis of sponsorship and better investment return (Giddy, 2003). 
He predicts that securitization transforms illiquid assets that contribute into tradable securities. This is aligned with managers that make over the risk using proper separation of financial assets from a corporation or financial institution with tiny revenue loss (Giddy, 2000). The assets, whenever alienated as of the originator, are used as support for high-quality securities planned to request to investors, counting residential market (Ripain, 2006). As documented in numerous securitization researches, spreads are regularly connected with credit rating, loan to value and transaction size in developed countries. There are few studies which have focused on other factors beyond credit rating especially in non US Asset (Fabozzi \& Vink, 2009). According to them, issue of spread towards primary market is frequently unnoticed, mutually in previous study. In practice, with significant unsatisfactory regard to the fact that determinant has vital significance when searching to sketch the concluding assessment of issuing securitization, it has become an underlying research issue of this study. For most corporations, as the loan originators, the decision to securitize the asset as the alternative cheaper source of fund (Giddy, 2003) and securities with corporate bond reduce the cost of bankruptcy by setting up a Special Purpose Vehicle. Likewise, portfolio managers on long term investors have the ability to invest in highly rated securities with better return (Giddy, 2001). As such, they have the ability to monetize non liquid assets (Eross et al., 2019), the transfer of credit risk and simultaneously to cater for their specific needs. Preceding researches in Western debt markets have characteristically investigated merely three aspects of determinants of primary market on recovery and default danger specifications, by examining the various factors which are credit enhancement, loan to value, credit rating maturity; seven marketability specifications including transaction size, lead managers quantity, tranche size, tranches quantity, credit rating agencies quantity, whether the subject is hold or not and lastly category of interest rate and one general risk feature which is money risk (Vink \& Thibeault, 2008). Regarding previous studies and based on the best of our knowledge, there is presently no research which analyzes the primary market spread determinants of the Malaysian securitization market.

The significance of the study is sufficiently noted on the three types of securitization, ABS, RMBS and CMBS which is yet to be investigated empirically. In addition, there is no experiential research analyzing the connection among primary market spread and leverage and liquidity as determinants of primary market spread in Malaysia. Prominently, a few is recognized regarding the places of both determinants in developing securitization framework in Malaysia on how these factors relate with spread which requires further study. In addition, the study extends further on the underlying theories and the models in terms of explaining those determinants of primary market spread studies.

\section{Literature review}

This section reviews the literature on models or theoretical explanations in relation to the primary market spread. There are a number of models or theoretical explanations relating to spread, which are theory of pricing based on literature from Merton (1974), Black and Cox (1976), Leland (1994), Duffee (2002), Duffie and Garleanu (2001) and Vink (2008). Theory of Capital Structure is based on Trade Off and Pecking Order. According to Merton (1974), it fixes the step for progression. The available literature has evolved with two major issues that developed the Merton's framework namely the approaches by Leland (1994) and Black and Cox (1976). These significant studies are discussed at the beginning to display the stages for the appraisal of the previous studies. In determining this valuable study, Black and Scholes (1973) propose how their loom can be employed in philosophy concerning the credit-risk debt valuation. In a significant study, Brennan and Schwartz (1978) formed the assessment of the problem of optimal capital structure and credit-risk debt employing numerical approaches. Black and Cox (1976) characterized an important version of Merton (1974) in numerous features. Primarily, they form safety covenants that permit the creditors to conquest the borrowing company when it is worth falls beneath a convinced threshold: $V_{B} . B e^{-\gamma(T-t)}$ in which $T-t$ is the stated time to the debt contract maturity. This imposes the default time vague, ex ante. Equity is no more a European call alternative on the borrowing of corporation's assets. It is a destitute call alternative on the corporation's assets which mention that the safety covenants presence transmits worth of equity to creditors. This permits the debt issuance at a tighter spread, ex ante. Next, they think higher on subordinated debt and they understand their valuations. Then, they expand a method to worth coupon-paying hazardous bonds by means of the endogenous default border, having and not having asset sale limitations, and show that asset sale restrictions and safety covenants can aim to progress the creditor's rights and augment the debt worth. Merton (1974) has valued an uncertain coupon bond considering that assets could be sold to finance coupon expenditure. Black and Cox (1976) evaluate Merton's formula and clear the valuation results in impressing asset sale limitations and safety covenants.

Previous studies focus more on Merton (1974) by clearly connecting a firm's default risk to the unpredictability in the firm's asset worth. Despite the fact that this row of study has been established in showing qualitatively significant features of pricing credit dangers, it is not much more of a triumphant practical application. There have been very little papers that even tried to price particular instruments. Others provided a standard reference in which they find that corporations are having very easy capital arrangements. A Merton kind of replica is incapable to value investment grade corporate bonds which are superior in comparison with naïve replica that is supposedly has no default risk. The shortage of achievement is indebted to the complexity of modeling sensible boundary situations. These limitations are in the occasion of evasion in which the separation of the worth 
of the firm is between claimants and conditions below in which defaults happen. Firms' capital arrangements are moderately multifaceted and precedence policies are frequently violated (Sharif et al., 2018). On these issues, substitute modeling method is followed in recent papers, including Duffie and Singleton (1997), Jarrow and Turnbull (1995) and Madan and Unal (1994). Scholars additionally pursue to expand Merton-style approaches to tackle these issues. It is notable to state that securitization has important effect throughout US subprime disaster. The disaster in praise marketplace from the spring of 2007 has worsened supervisors, surprised investors and weakened banking industry's solvency Taylor (2010). Altman (2007) discusses that praise as marketplace pricing of praise danger was excessive and a credit bubble was in attendance. As disaster struck, Fender and Hordahl (2007) as well as Turnbull (2008) explain the untimely growth of the disaster and the way it has extended all through the financial scheme.

Despite the fact that its effect has been extensively felt, the beginning of fresh turmoil exists in loans solvency. Principally, fairly particular division of the US prearranged merchandise marketplace that is a sub-prime Residential Mortgage- Backed Securities market. Commentators have credited the issues to a main refuse in below-script of principles joint with a recession in the housing marketplace persuaded by increasing interest rates (Perraudin \& Wu, 2008). Experimental analysis on praise spreads on ABS is not easy compared to the same action for business bonds which are known as the multifaceted arrangement connected with a securitization transaction.

The financial disaster that started a slump in US housing marketplaces as a rising quantity of hedge and banks funds created considerable losses on MBS and subprime mortgages. The disaster has gradually structured as the primary months of 2007. For example, at the end of 2007 February, the Federal Home Loan Mortgage Corporation (Freddie Mac) promoted that it will no more purchase the riskiest subprime mortgages. It means that a great piece of the securitization and origination process of subprime MBS will force to be transferred to the private section. Standard and Poor and Moody's Investor Services that demoted over 100 bonds, it was reversed by second-line subprime mortgages in June 2007. However, a main pace in the direction of a spiraling disaster was highlighted by Fitch Ratings' choice in August 2007 to demote one of the main companies particularly in intermediation of mortgage in the subprime division, Countrywide Financial Co. consequently, Countrywide was enforced to use the whole $\$ 11.5$ billion obtainable in its credit lines through additional banks. It was a tender proof that the disaster was intended to increase from the finance marketplace to the monetary mediators reversing its operators (Guidolin \& Tam, 2013).

\section{Research methodology}

\subsection{Primary market spread}

The primary market refers to the initial market in which new issues of bonds are distributed or placed but before the official issue on the (optional) date of the bonds. Different from straight bond in which the transaction will be done through bond dealer, the asset-backed securitization (ABS) will be issued by special-purpose vehicle (SPV) through the bank dealer. All the financial institutions that have right to issue asset-backed securitization (ABS) must have a license from the Securities Commission (SC).

To determine the yield of asset-backed securitization (ABS) in the primary market, it will be based on the length of maturity and may also depend on the underlying assets itself. Therefore, one of the complications in the yield is that it is different both in maturity and underlying assets to be securitized, as opposed to normal bond; hence it will represent a different yield. This is justified as ABS in most cases will be issued in tranches that have different maturity and yield (Gangwani, 1998; Vink, 2008). When issuing asset-backed securitization (ABS) to the investors, the special- purpose vehicle (SPV) has the obligation to pay the interest and principal. In asset- backed securitization (ABS), the payment of interest is an obligation on each of the bond issues which are dependent on the underlying lease payments from the originator. These payments are structured on matching tenures with the sub-lease. Thus, the ability of the originator to pay the lease assets will influence the interest determination. Besides, the interest obligation, when issuing the ABS, SPV also has the obligation to repay the principal to the ABS holders. The final bullet-structured principal repayments at the expected maturity for every bond category are reliant on the auction of the pledged specifications, each using the buy alternative or throughout sending to third parties. The loan spread (main marketplace spread) characterizes the price for the danger connected with the safety on the foundation of data at the time of issue. In the study example, the spread is described as the margin achieved by the security at issue over an equivalent benchmark. The spread is shown in basis points. For floating rate problems, the spread is stated as a quoted margin on top of the Interbank Offered Rate. For permanent rate problems, the spread is shown in foundation points in excess of the closest standard of corresponding maturity.

\subsection{Data}

Greene (2003) mentions that the investigator might be permitted to inspect the dynamics of alter in short time series recurring remarks of cross sections by means of panel data investigation. Furthermore, it permits the investigator to have an immense 
flexibility regarding distinctions modeling and to arrest diverse performance across personal cross section. Furthermore, it supplies additional flexibility, supplementary degree of freedom, supplementary spread, fewer collinear between variables while employing panel data that will create competence in generate results. Furthermore, it enhanced the quantity and quality of information by considering different dimensions. The complex behavioral approaches can be catered through panel data investigation. Since panel data is connected to personal firms, eventually this leads to heterogeneity. The heterogeneity issue obviously has been considered by panel data approximation by allowing for personal precise variables. Consequently, this study inspects the yearly information of 90 tranches of securitization from January 2004 to December 2012 of nationwide markets in Malaysia. The final samples consist of 346 observations, using panel data analysis. The final sample of the acquirers and targets is compiled applying the following criteria:

i) Each Malaysian company issues Asset-Back Securities as rating by RAM

ii) The transaction is announced and completed between 2004 to 2012.

\subsection{Internal Determinants}

In the non-crisis eras and particularly in the result of the Great Crisis, we detect that for major spreads, yields tend to regulate in the instructions - uphill for achievements on high (low) default (liquidity) risk bonds, and downward for yields on high (low) default (liquidity) risk bonds - that are companionable with mean-reversion and spreads' stationarity(Guidolin \& Tam, 2013).Sabry and Okongwu (2009) prove that in the U.S. context, securitization has augmented the accessibility of credit and reduced its cost. More precisely, they display that a 10 percent growth in securitization action suggests a reduction of among 4 and 64 basis points on yield spreads, relying on the exact type of the loan. The shadow banking scheme in the form of special investment vehicles (SIVs) was extremely leveraged. Characteristically the leverage ratio was about 1:15 but in some cases, as the study for yield intensified in a bull market of constriction credit spreads, the leverage ratios gotten 1:40 and even 1:50. To put this into viewpoint, the hedge fund Long Term Capital Management (LTCM) was operating leverage of 1:30 at the time of its demise and made important disturbance of the marketplaces in 1998 all lonely. In operation, what occurred in $2007-08$ was hundreds of LTCMs, all gearing up to an advanced leverage ratio, all making the similar trade, and all failing. Kleimeier and Megginson (1996) study leverage is extremely definitely connected with loan spread. The coefficients for the leverage factor in the regressions accessible in columns 11 and 12 average a significant 63.6, inferring that growing a project's leverage from, say, 0.60 to 0.70 will reason loan spreads to upsurge by about 6.4 basis points.

\subsection{External Determinants}

The spread is both an economically and statistically important forecaster of inflation (Kozicki, 1997). The spread clarifies among one percent (for France) and thirty three percent (for Sweden) of the disparity in inflation at a four-year horizon (i.e., over the year ending four years in the future). At this prospect, approximations of the coefficient on the spread are statistically and positive significant for six of the ten countries examined. Furthermore, to being statistically significant, the spread is an economically significant forecaster inflation. For instance, all else equal, a one hundred basis-point reduction in the UK yield spread will end to a 1.26 percentage point decrease in anticipated UK inflation at a four-year horizon.

Initially, in US bond marketplaces, Longstaff and Schwartz (1995) originated proof of a negative relation for both variations in the short-term interest rate and variations in business asset value. A weaker but important negative relationship among changes in credit spreads and interest rates was similarly originated by Duffee (1998) while Neal et al. (2000) recognized a negative association only for the short term and a setback to a positive connection for the long run. Plosser and Rouwenhorst (1994) state that the spread's conduct is dependable with real commercial cycle concept. In a real commercial cycle model, comparatively great anticipated prospect development would suggest rising real interest rates and a steepening of the term structure. The converse would happen if growth was anticipated to slow. Therefore, the spread can signal anticipated variations in the economy that are regard to nonmonetary shocks.

\subsection{Econometric Specification}

A panel has the form $X_{i t}, i=1, \ldots, N t=1, \ldots, T$, where $i$ is the individual dimension and $t$ is the time dimension. A general panel data regression model is written as:

$$
y_{i t}=\alpha+\beta^{\prime} X_{i t}+u_{i t}
$$

Therefore, by integrating Eq. (1) to Eq. (2), we could achieve to following equation: 
Table 1 supplies data on the amount of correlation among the explanatory factors deployed in the multivariate regression examination. The matrix displays that in general the correlation among the bank-specific factors is not robust signifying that multicollinearity issues are either not simple or non-existent. Kennedy (2008) states that multicollinearity is an issuance the correlation is above 0.80 , which is not the case here.

\section{Empirical findings}

The regression outputs concentrating on the relationship among monetary institutions' success and the descriptive factors are shown in Table 2. To jam space, the full regression outputs, that comprise both firm- and time-specific fixed impacts are not shown in the paper. Numerous general comments concerning the test outputs are warranted. The model executes practically well, with most factors remaining stable across the numerous regressions tested. The explanatory power of the models is likewise sensibly high, as the $F$-statistics and Wald $\chi^{2}$ statistics for all models are important at the one percent level.

Table 1

Correlation matrix for the explanatory variables

\begin{tabular}{cccc}
\hline Independent Variables & LLQD & LLVG & LINFL \\
\hline LLQD & 1 & & \\
LLVG & -0.052 & 1 & 1 \\
LINFL & 0.031 & -0.189 & 0.013 \\
LINTR & 0.070 & 0.023 & 1 \\
\hline
\end{tabular}

Table 2

Multivariate regressions results

\begin{tabular}{|c|c|c|c|c|}
\hline & $\begin{array}{c}\text { (1) } \\
\text { Fixed effects } \\
\end{array}$ & $\begin{array}{c}\text { (2) } \\
\text { Random effects }\end{array}$ & $\begin{array}{c}(3) \\
\text { Fixed effects } \\
\end{array}$ & $\begin{array}{c}\text { (4) } \\
\text { Random effects }\end{array}$ \\
\hline CONSTANT & $\begin{array}{l}5.486 * * * \\
(239.69)\end{array}$ & $\begin{array}{l}5.382 * * * \\
(81.09)\end{array}$ & $\begin{array}{c}-4.882 * * * \\
(-2.88)\end{array}$ & $\begin{array}{l}-2.805 \\
(-1.64)\end{array}$ \\
\hline \multicolumn{5}{|l|}{ Firm Characteristic } \\
\hline LLQD & $\begin{array}{c}-0.0677 * * \\
(-2.19)\end{array}$ & $\begin{array}{c}-0.099 * * * \\
(-3.40)\end{array}$ & $\begin{array}{l}-0.023 \\
(-0.96)\end{array}$ & $\begin{array}{c}-0.053 * * \\
(-2.23)\end{array}$ \\
\hline LLVG & $\begin{array}{c}0.0483 * * \\
(-2.21)\end{array}$ & $\begin{array}{l}-0.042 * * \\
(-2.09)\end{array}$ & $\begin{array}{l}0.002 \\
(0.15)\end{array}$ & $\begin{array}{l}-0.003 \\
(-0.17)\end{array}$ \\
\hline \multicolumn{5}{|l|}{$\begin{array}{c}\text { Economic and Market } \\
\text { Conditions }\end{array}$} \\
\hline LINF & - & - & $\begin{array}{c}2.567 * * * \\
(6.93)\end{array}$ & $\begin{array}{c}2.085^{* * *} \\
(5.58)\end{array}$ \\
\hline LINT & - & - & $\begin{array}{c}-1.213 * * * \\
(-13.21)\end{array}$ & $\begin{array}{c}-1.213 * * * \\
(-12.75)\end{array}$ \\
\hline$R 2$ & 0.1330 & 0.1514 & 0.4399 & 0.4349 \\
\hline$F$-statistic & $5.33 * * *$ & - & $57.53 * * *$ & \\
\hline Wald $\chi^{2}$ & - & $16.54 * * *$ & - & $208.67 * * *$ \\
\hline$x^{2}$ & $8.45^{* *}$ & - & $95.61 * * *$ & \\
\hline No. of observations & 387 & 387 & 387 & 387 \\
\hline
\end{tabular}

Notes: Values in parentheses are t-statistics.***, ${ }^{* *}$, and * indicates significance at 1,5 , and $10 \%$ levels.

In identifying the determinants of primary market spread in Malaysia, statistical data tabulated in Table 2 shows the estimation results of primary market securitization in Malaysia. The estimation output exhibits that coefficients for liquidity, leverage and interest are negatively significant at 0.05 and 0.01 level, while coefficients for inflation is positively significant at 0.01 level for estimation model. The significant negative relationship at 0.01 level from liquidity, leverage and interest on the primary market spread is sustained with the findings of Gabbi and Sironi (2002) and Firla-Cuchra (2005). It is a significant and negative relationship at 0.1 level from inflation to spread. The F-statistic regression results for estimation models reject the null hypothesis meaningfully that coefficient values on descriptive variables for primary market spread are zero (0) worth. During the panel equation evaluation for primary market spread, the noteworthy of F-statistic at 0.01 level in the fixed effect test displays that the fixed effect approximation is more desirable. The survival of heteroscedasticity is obvious over the important result made as of the F-statistic in the pooled OLS. This permits one to defend the appropriate employment of fixed effect model and GLS with random effect model. Consequently, the Fixed Effect seems to be the best model to clarify factor that influence primary market spread. In the designated model of the fixed effect, there are important positive associations at 0.01 level as for inflation to spread. Additionally, there is an important negative association at 0.01 level as of interest to spread. The inflation coefficient is presenting the uppermost worth between all other factors, in which inflation upsurge may permit an increase in the spread. This indicates that the FE is fit and valid in analyzing the statistical data collected from the model. The influence of LINT on 
spread is important in the regression models, suggesting that throughout the period underneath study the Malaysia primary market spread.

\section{Conclusion}

The empirical findings of this study suggest that all the firm-specific determinant variables have a statistically significantly impact on the primary market spread in Malaysia. During the period under study, the results suggest that Liquidity is negatively related to primary market spread it means that the more liquid of the firm less spread or margin. The experiential results of this research propose that all the firm-specific determinant factors have a statistically meaningfully effect on the primary market spread in Malaysia in internal regression model and it is stimulating to note that the coefficient of the variable lose its explanatory power once other macroeconomic and monetary indicators are managed for. Throughout the period underneath research, the outputs propose that leverage positively connected to primary market spread. The experiential results seem to propose that the liquidity is negatively connected to Malaysia primary market spread. Instead, inflation have definitely and interest have negatively connection and meaningfully clarified the variations in the primary market spread of Malaysia companies.

The results of this research have substantial policy significance. It can be discussed that the more spread of the company will be capable to offer more new merchandises and services. Therefore, the technology advancement role is chiefly significant given that a firm with comparatively more advanced technologies may have a supplementary benefit over its peers. The sustained achievement of the Malaysia securitize relies on its effectiveness, spread and competitiveness. Forthcoming study could comprise more factors including firm size, tranche size, debt and gross domestic product that relate to the primary market spread. Regarding the methodology, a time series and generalize approach of moments could also be employed.

\section{Acknowledgement}

The author would like to thank Universiti Teknikal Malaysia Melaka (UTeM) and Centre for Technopreneurship Development (CTED) for their support in obtaining materials and funding for this invaluable research.

\section{References}

Ali, R., Ismail, S., \& Bakri, M. (2015). Proposed Islamic educational loan-backed securities for quality life of university graduates in Malaysia. Procedia-Social and Behavioral Sciences, 201, 85-92.

Altman, E. I. (2007). Global debt markets in 2007: new paradigm or the great credit bubble?. Journal of Applied Corporate Finance, 19(3), 17-31.

Bakri, M. H., Ali, R., \& Ismail, S. (2015). The Study of Residential Mortgage Backed Securities During Subprime Mortgage: Malaysian Experience. Advanced Science Letters, 21(5),1468-1472

Bakri, M. H., Ali, R., \& Ismail, S. (2016). Developing Primary Market Spread and Measuring Financial Performance of Staff Housing Government Loans. Proceedings of the 1st AAGBS International Conference on Business Management, $501-511$.

Bakri, M.H., Sufian, F., Baharom, A.H., \& Ismail, S. (2018). Determinant of securitization spread in Malaysia. International Journal of Business and Society 19(3), 904-917.

Bakri, M. H, Dabas. N, Ismail, S., \& Baharom, A. H. (2017). Islamic student financing back securitization in Malaysia. Advanced Science Letters, 23(9) 8090-8093

Brennan, M. J., \& Schwartz, E. S. (1978). Corporate income taxes, valuation, and the problem of optimal capital structure. Journal of Business, 51(1), 103-114.

Black, F., \& Scholes,M. (1973). The pricing of options and corporate liabilities. Journal of Political Economy 81, $637-654$.

Black, F. \& Cox, J. (1976). Valuing corporate securities: Some effects of bond indenture provision, The Journal of Finance, 31, 857-934.

Duffie, D., \& Singleton, K. J. (1997). An econometric model of the term structure of interest-rate swap yields. The Journal of Finance, 52(4), 1287-1321.

Duffie, D., \& Garleanu, N. (2001). Risk and valuation of collateralized debt obligations. Financial analysts journal, 57(1), 4159.

Duffee, G. R. (2002). Term premia and interest rate forecasts in affine models. The Journal of Finance, $57(1), 405-443$.

Eross, A., Urquhart, A., \& Wolfe, S. (2019). An early warning indicator for liquidity shortages in the interbank market. International Journal Finance \& Economics, 24(1), 1-13.

Fabozzi, F. J. (1998). Valuation of fixed income securities and derivatives. Boston: Frank J Fabozzi Associates.

Fender, I., \& Hördahl, P. (2007). Overview: credit retrenchment triggers liquidity squeeze. BIS Quarterly Review, 1-16.

Vink, D., \& Fabozzi, F. J. (2009). Non-US asset-backed securities: Spread determinants and over-reliance on credit ratings.

Fabozzi, F. J., \& Vink, D. (2011). Determinants of primary market spreads on UK residential mortgage-backed securities and the implications for investor reliance on credit ratings. The Journal of Fixed Income, 21(3), 7-14.

Fabozzi, F. J., \& Vink, D. (2012). Looking beyond credit ratings: Factors investors consider in pricing European asset-backed securities. European Financial Management, 18(4), 515-542. 
Firla-Cuchra, M. (2005). Explaining launch spreads on structured bonds. Working Paper. Oxford University.

Firla-Cuchra, M., \& Jenkinson T. (2006) Why are securitization issues tranched?. Working Paper. Oxford University.

Fong, L.F. (2013). Malaysia leading in Global Sukuk. The Star. (online)http://www.thestar.com.my

Gabbi, G., \& Sironi, A. (2002). Which factors affect corporate bond pricing. Empirical evidence.

Gangwani, S. (1998). Speaking of Securitization. Delloite \& Touche, 3(4), NewYork, July 20

Guidolin, M., \& Tam, Y. M. (2013). A yield spread perspective on the great financial crisis: Break-point test evidence. International Review of Financial Analysis, 26, 18- 39.

Gordon, M. (1959). Dividends, earnings, and stock prices. Review of Economics and Statistics, 41(2), 99-105.

Giddy, I., (2000). New Developments in Asset-Backed Securities. Workshop, Host Excellent International, Johannesburg, South Africa.

Greene, W. H. (2003). Econometric analysis. Pearson Education India.

Ingersol, J. E. (1987). Theory of Financial Decision Making. Totowa, N.J.: Rowman \& Littlefield.

Jarrow, R. A., \& Turnbull, S. M. (1995). Pricing derivatives on financial securities subject to credit risk. The Journal of Finance, 50(1), 53-85.

Kleimeier, S. \& Megginson, W.L. (2001). An empirical analysis of limited recourse project finance. Working Paper, University of Oklahoma, Michel F. Price College of Business.

Kennedy, P. (2008). A Guide to Econometrics. Malden, Mass: Blackwell Publishing.

Kozicki, S. (1997). Predicting real growth and inflation with the yield spread. Economic Review-Federal Reserve Bank of Kansas City, 82, 39-58.

Leland, H. E. (1994). Corporate debt value, bond covenants and optimal capital structure. Journal of Finance, 49, $1213-52$.

Longstaff, F. A., \& Schwartz, E. S. (1995). A simple approach to valuing risky fixed and floating rate debt. The Journal of Finance, 50(3), 789-819.

Lumpkin, S. (1999). Trends and developments in securitization. Financial Market Trends, 74(7), 25-57.

Madan, D. B., \& Unal, H. (1994). Pricing the risks of default, Working Paper. Wharton School, University of Pennsylvania.

Merton, R. C. (1974). On the pricing of corporate debt: The risk structure of interest rates. The Journal of finance, 29(2), 449470 .

Neal, B. C., Rodgers, A., Clark, T., Gray, H., Reid, I. R., Dunn, L., \& MacMahon, S. W. (2000). A systematic survey of 13 randomized trials of non-steroidal anti-inflammatory drugs for the prevention of heterotopic bone formation after major hip surgery. Acta Orthopaedica Scandinavica, 71(2), 122-128.

Plosser, C. I., \& Rouwenhorst, K. G. (1994). International term structures and real economic growth. Journal of Monetary Economics, 33(1), 133-155.

Perraudin, W., \& Wu, S. (2008). Determinants of asset-backed security prices in crisis periods. Available at SSRN 1340008.

Riddiough, T. J. (1997). Optimal design and governance of asset-backed securities. Journal of Financial Intermediation, 6(2), 121-152.

Ripain, N., Ali, R., Serguieva, A., \& Ismail, S. (2006). Growth and Outlook of Asset-Backed Securitization in The Malaysian Capital Market: The Case Study of Sunway City Berhad.

Seagraves, P. A. (2012). A Multi Factor Probit Analysis of Non-Performing Commercial Mortgage Backed Security Loans. Georgia State University.

Sharif, S. M., Nizam, N. Z., Rashid, N. A., Masrom, N. R., Bakri, M. H., \& dan Teknousahawanan, F. P. T. (2018). Role of values and competencies in university intellectual property commercialization: A critical review. The Turkish Online Journal of Design, Art and Communication, 887-904

Schiller, R. J. (1989). Market Volatility. Cambridge, MA: MIT Press

Summers, L. H. (1986). Does the stock market rationally reflect fundamental values. Journal of Finance, 41(3), 591-601.

Taylor, M.P. (2010). The global financial crisis: introduction and overview. Applied Financial Economics , 20(1), 3-5.

Turnbull, D., Barrington, L., Torres, D., \& Lanckriet, G. (2008). Semantic annotation and retrieval of music and sound effects. IEEE Transactions on Audio, Speech, and Language Processing, 16(2), 467-476.

Vink, D. (2008). An Empirical Analysis of Asset-Backed Securitization, 21st Australasian Finance \& Banking Conference 2008 Paper.

Vink, D., \& Thibeault, A. E. (2007). An empirical analysis of asset-backed securitization. NRG Working Paper Series. Nyenrode Business Universiteit

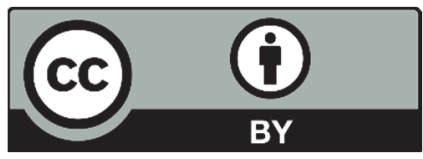

(C) 2020 by the authors; licensee Growing Science, Canada. This is an open access article distributed under the terms and conditions of the Creative Commons Attribution (CC-BY) license (http://creativecommons.org/licenses/by/4.0/). 